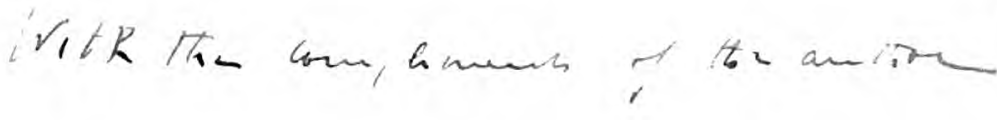

\title{
Les
}

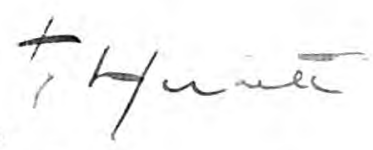

\section{ports américains}

\section{du Nord-Ouest}

\author{
PAR
}

\section{FRANÇOIS HERBETTE}

AGRÉGÉ D 'HISTOIRE ET DE GÉOGRAPHIE

CHARGE DES TRAVALX PRATIQUES DE GGOGRAPHIE

A LA FACLLTÉ des LetTRES DE L I'NIVERSITÉ DE PARIS

Extrait des Annales de Geographie, tome XXII, I913

(No 122 du 15 mars 1913).

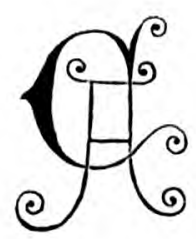

Librairie Armand Colin

5, Rue de Mézières, Paris, $6^{\circ}$ 